\title{
The Utilization of Long-Term Relationship and Supply Chain Performance in Improving SMEs Performance
}

\author{
Nur Prima Waluyowati, Surachman, Djumahir, Siti Aisjah \\ Department of Management, Economics and Business Faculty, Brawijaya University, Malang, Indonesia \\ Email address: \\ imawaluyowati@gmail.com (N.P. Waluyowati) \\ To cite this article: \\ Nur Prima Waluyowati, Surachman, Djumahir, Siti Aisjah. The Utilization of Long-Term Relationship and Supply Chain Performance in \\ Improving SMEs Performance. American Journal of Theoretical and Applied Business. Vol. 4, No. 3, 2018, pp. 79-89. \\ doi: 10.11648/j.ajtab.20180403.11
}

Received: September 25, 2018; Accepted: November 1, 2018; Published: December 24, 2018

\begin{abstract}
Since 2015, the Association of Southeast Asian Nations (ASEAN) single market or popularly known as ASEAN Economic Community (AEC) has been implemented. AEC provides opportunities to improve the economy of the region through the expansion of the international market for competitive products. With trade barriers are getting smaller, it is expected that many local products, especially those produced by SMEs could penetrate the ASEAN market. The main purposes of this study is to prove that the long-term relationships and the performance of the supply chain is an essential element in generating the company's performance. More specifically, the study aims to to analyze the direct effect of the long-term relationship on supply chain management and indirect effect trough the mediation of information technology, supply chain integration and information sharing.. This study was conducted on 194 respondents (SMEs) in Malang, East Java (Indonesia) using analytical tools of Structural Equation Modelling (SEM). The results showed that the long-term relationship in SMEs directly and significantly affect the use of information technology, information sharing, and integration of supply chain and supply chain performance. In addition, long-term relationship indirectly and signifiantly affect the performance of the supply chain through the infromation technology, supply chain integration and information sharing. However, the direct effect of information sharing on supply chain performance is not significant. These results demonstrate that the long-term relationships are crucial for SMEs in Malang to face the increasingly fierce competition in the future.
\end{abstract}

Keywords: Long Term Relationships, Supply Chain Integration, Supply Chain Performance, Information Technology, Information Sharing, Small and Medium Enterprises (SMEs)

\section{Introduction}

Since 2015, the ASEAN single market or popularly known as ASEAN Economic Community (AEC) has been implemented. AEC provides opportunities to improve the economy of the regions through the expansion of the international market for regional competitive products. AEC creates trade barriers much smaller, and is expected that many local products, especially those produced by Small and Medium Enterprises (SMEs) could penetrate the ASEAN market. The implementation of the AEC will be also a challenge for local government in economic development efforts, and more particularly the empowerment of SMEs in Indonesia to compete in the ASEAN market.

In the ASEAN market and other markets, competition among companies tends to focus on the low cost competition, where the product at a lower cost with a more superior quality requires the ability to manage the supply chain. Supply chain management can produce efficient and effective results by implementing a long-term relationship, information technology, integrated supply chain, and information sharing. Those competitive advantage factors should also be implemented by the SMEs in order to have competitive advantages. The main purpose of this research is to prove that the long-term relationships and the performance of the supply chain is an essential element in generating the company's performance effectively and efficiently which $\mathrm{Li}$ et al that it requires the mediation of information technology, information sharing and supply chain integration [1].

The long-term relationships will be able to make the company maintains both suppliers and consumers to always be in the chain of partnerships. According to Anatan and 
Koçuglu et al, retaining suppliers and consumers in a partnership can impact on the ease to constantly innovate on products produced by company and the flow of information, material and financial resources between the elements in the supply chain and will ultimately affect the supply chain performance [2-3]. In addition, Prajogo and Olhager argue that long-term relationship has direct effect on the supply chain performance, suggesting that the ability to strengthen the network is very important beside the internal capacity [4]. To strengthen the network needs to integrate and link the companies in the supply chain, in order to coordinate and communicate effectively and efficiently by using information technology.

The use of information technology in supply chain management makes better materials, information and finances flow [5]. Study by Aprianingsih et al show that the use of information technology directly affects the supply chain performance [6]. Furthermore, the process of integrating and linking companies in the supply chain means integrate among companies in the supply chain, well known as supply chain integration. Levi et al., Johnson et al., and Bagheri et al state that supply chain integration indicates cohesiveness in the flow of information, financial and material in performing activities in supply chain management [7-9].

Sharing information is another factor that can make effective and efficient in linking and integrating the coordination and communication among companies in the supply chain. Sharing information is the information exchange both quantitatively and qualitatively between the partners in the supply chain [1]. Anatan, Koçuglu et al, and Ariani et al believe that sharing information also affects the performance of the supply chain $[2-3,10]$. The object of this research is the SMEs in Malang, East Java as its represent the conditions experienced by the SMEs in Indonesia in general.

\section{Literature Review}

\subsection{Supply Chain Management}

Supply chain management (SCM) is the management of various material procurement and service activities, conversion from semi-finished goods into finished products, and product delivery through a distribution system [5, 11-12]. According to Simchi-Levi et al definition of supply chain management emphasizes more on the efficient integration between suppliers, manufactures, warehouses and shops, so that the products can be distributed on the right number, location and time, and in only one order to minimize the wide system costs by fulfilling requirements in service [11].

The definition above emphasizes from upstream to downstream activity management (along the supply chain) and integration among elements in the supply chain. The definition of supply chain management has a very broad meaning, and requires understanding at each stage of the activities. Supply chain consists of suppliers, companies, distributors, retailers and consumers [11]. However, supply chain elements may consist more or less than five elements.

\subsection{Buyer-Supplier Relations}

The supplier-buyer relationship is a part that cannot be separated from SCM. The supplier-buyer relationship is a cooperative relationship between the companies and its suppliers. The buyer-supplier relationship in the supply chain means that the supplier and buyer have cooperation, which is integrated between the two. A strategic supplier relationship management (SRM) system aims to collaborate with suppliers, so that the company can develop new products competitively and produce goods efficiently [13].

\subsection{Supply Chain Performance}

The results of a supply chain management implementation in a company are measured by the performance of the supply chain. Supply chain performance is the processes carried out by the company in managing the flow of material, information and funds in its supply chain [4]. Supply chain performance is the responsibility of the supply chain division in a business. Supply chain division in a company may below the functional area of operations or may a separate part of a company, depending on the needs of the company.

One of the most popular supply chain performance measurement tool is supply chain operations reference (SCOR) model, that was designed by the supply chain council (SCC). According to Hwang et al SCOR model integrates three main elements in management, namely business process reengineering (BPR), benchmarking, and measurement process [14]. BPR redesigns business processes and adjusts between the availability of company resources and the current business development, where benchmarking is an activity to obtain performance data or information from similar companies in order to be implemented in the company, and the measurement process is measuring and controlling the process of supply chain management, and correcting the deviations that may occur.

\section{Research Concepts and Hipotesis}

\subsection{Conceptual Framework Research}

The nature of the supply chain is horizontal which means that the enterprises in the supply chain are in the same level. This emphasizes that buyers and suppliers in the supply chain have a series of no higher or lower position. In general, the supply chain involves a variation of the steps. According to Chopra and Meindl. the steps in the supply chain involve suppliers, manufacturers, distributors, retailers and consumers [15]. In delivering optimal supply chain management, a partnership is formed to run by corporations or businesses that have interrelationship and commitment in flowing goods, services, data and information. Partnership brings elements such as long-term relationships and mutual concern (communication) which then form the basis for a long-term relationship. The rapid development of information technology helps to coordinate among the 
partners which then expected to be the glue in a long-term relationship.

Some facilities that use information technology are in buyer supplier relationships, e-procurement, and e-commerce in which the process is carried out the Electronic Data Interchange (EDI) and Interorganizatioanal System (IOS). Managing the supply chain and information technology is part of the integration of information and sharing information, which is known as supply chain information integration [4]. The information flow will be more effective and efficient when using information technology. Previously, long-term relationships between partners in the supply chain partnerships, triggering supply chain integration. The integration of the supply chain will be much better if supported by information technology and information sharing. Good relationships between these elements may lead to a reduction of inventory, timeliness, number of shipments, specification of products / raw materials, and speed product development time. The relations among these variables can be seen in Figure 1.

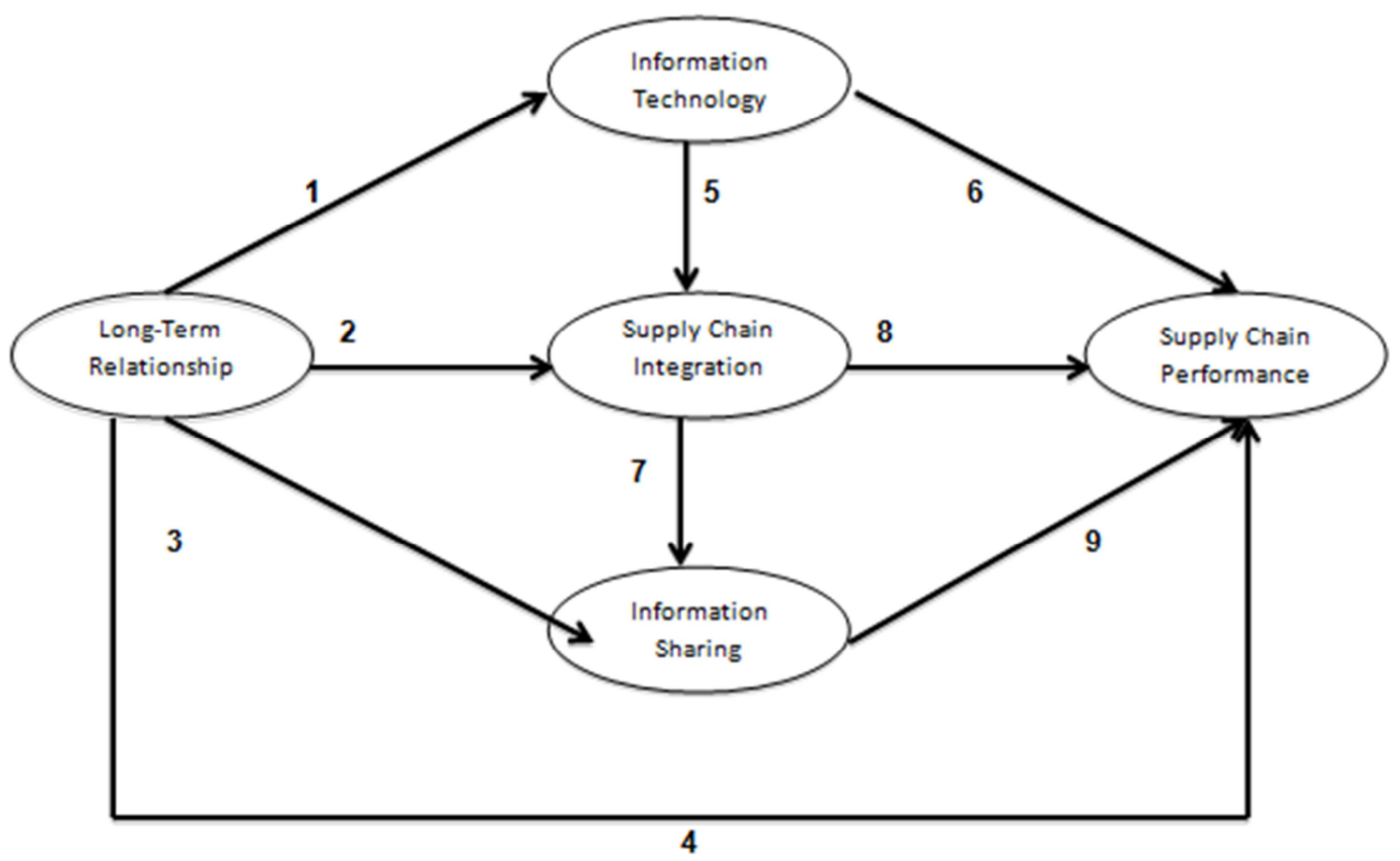

Figure 1. Conceptual Framework Research.

Source: Researcher, 2015

Note:

1: $[4,16]$

2: [4, 17];

3: $[4,16]$;

4: $[4,10,17]$

5: [10]

6: [6]

7: [3]

8: $[1-3,10]$

9: $[2-3,10]$

\subsection{Research Hypothesis}

Based on the research framework and descriptions in the previous section, the hypotheses of this study are as follows:

H1: Long-term relationship positively effects information technology

$\mathrm{H} 2$ : Long-term relationship positively effects information sharing

H3: Long-term relationship positively effects supply chain integration

H4: Long-term relationship positively effects supply chain performance

H5: Technology information positively affects supply chain integration

H6: Technology information positively affects supply chain performance

H7: Integration positively effects supply chain to share information

H8: Supply chain integration positively affects supply chain performance

H9: Information sharing positively effects supply chain performance

\section{Research Method}

The research methods used to test hypotheses associated 
with the formulation of the problem and research objectives. This study used a quantitative approach collected using survey method. This research is an explanatory research, aims to get an explanation of the causality among variables through hypothesis testing. Generally, this research analyzes the performance of the supply chain in SMEs in Malang and investigates the factors that influence it, such as information sharing, supply chain integration, information technology and long-term relationship. Survey methods conducted by distributing questionnaires to respondents, managers or owners of the SMEs who run the supply chain management.

\subsection{Population and Sample}

According to Central Bureau of Statistic (BPS) of East Java, the number of SMEs in Malang amounted to 1360 SMEs in 2012 [17],. The population in this study is the SMEs in Malang, with the following criteria:

a. SMEs with the field of food and beverages, fashion and crafts.

b. SMEs are already doing business at least (three) years

c. SMEs are runring supply chain management

This research is a survey method, so it does not need the entire population. In this study, the number of samples is determined using Slovin formula

$\mathrm{N}=376$ People

$$
\mathrm{e}^{2}=(5 \%) / 100=0.05
$$$$
\mathrm{e}^{2}=0.05^{2}(0.05 \times 0.05=0.0025)
$$

$$
\mathrm{n}=\frac{376}{1+.\left(376 \times 0.05^{2}\right)}
$$

$\mathrm{n}=376 \times 0.0025+1=1.94$

$\frac{200}{1.94}=193.81$ counted as 194 respondents

Based on the Slovin formula the sample number is 194 respondents. Respondents in this study are managers connected in supply chain management to the sales process, purchasing raw materials and intermediate goods (raw materials and intermediate goods), distribution, and warehousing in SMEs in Malang.

\subsection{Sampling Technique}

This study used stratified random sampling method. Stratified random sampling is a sampling technique by observing strata in the population [26]. The samples of this study are as follows:

Table 1. Samples with Strata by Region and Type of Business.

\begin{tabular}{lllll}
\hline Region & Food and Beverages & Fashion & Handicraft & Number of SMEs \\
\hline Malang Regency & 39 & 14 & 38 & 91 \\
Malang City & 13 & 16 & 28 & 57 \\
Batu City & 21 & 7 & 18 & 46 \\
Total & 73 & 37 & 84 & 194 \\
\hline
\end{tabular}

Source: Field Data, 2015

\subsection{Structural Equation Modeling (SEM)}

The study used AMOS program as the analysis method. AMOS program is part of Structural Equation Modeling (SEM). The estimiation of SEM parameters are generally based on the method of maximum likelihood (ML ML estimation method requires the assumption that must be fulfill, such as the sample should be large (asymptotic), the distribution of observed variables in multivariate is normal, hypothesized model is valid.

This study will use two phases (two-stage process) analysis of SEM models as recommended by Hair et al [18]. The first stage, Confirmatory Factor Analysis (CFA) was conducted to measure the validity of each instrument or measurement model (measurement model). Second, the overall SEM will be estimated for the chosen model. Between these two stages, the model is estimated to be modified and evaluated based on the measurement model fit, the significance of variables, and the alignment of the hypothesis. In this study, there are some steps that will be done before doing the analysis and SEM model test with twostage process, among others:

First, conducting data preparation (data screening) and initial analysis prior evaluating the measurement to make sure there are no outliers or missing data in the model. Data screening is done manually by looking at the maximum, minimum, average, median or frequency. Furthermore, after ensuring that no data is lost or doubt then conducting an assessment on multivariate outliers as described by Kline, where each observation is possible to have two or more extreme values [19].

Second, testing the normal distribution through skewness indicators, kurtosis and mardia coefficient. Furthermore, test multivariate normality models by looking at the skewness, kurtosis, and normality value of the multivariate models (Mardia Coefficient). Based on the cut-off value of 3 for skewness, kurtosis and value of 8 to 10 for normality multivariate models can be concluded that the data and multivariate model used in this study had a normal distribution [20].

Third, evaluating the measurement model to determine the validity and reliability level of indicators that measure latent variables. In this case the validity and reliability criteria of research instrument refers to convergent and discriminant validity as well as composite reliability. The testing measurement model in this study aimed to assess the indicator of variable which describes as latent variables or constructs that cannot be measured directly, thus requiring an analysis of the indicators to give meaning on symbols given to construct variables. Empirical analysis aims to test the validity and reliability levels that reflect the parameters on 
the latent variables are built based on theory and empirical studies. In this study used five latent variables consist of long-term relationships, information technology, information sharing, supply chain integration, and supply chain performance to the determin indicator that is reflective.

\section{Results}

\subsection{Research Hypothesis Test}

In general, the SEM models measure the factors that affect the supply chain performance. Based on the development of theoretical concepts and previous research can be explained that the role of information technology, long-term relationship, supply chain integration and information sharing have alleged effect on supply chain performance. Besides having a direct relationship, each of the variables is interrelated with one another before they impact supply chain performance. The results of hypothesis testing are described in the table 2. If the p-values less than 0.05, then the relationship between variables is significant, and does not significant if the p-values more than 0.05 [21]. The research hypotheses tests are as follows:

Table 2. Results of Hypothesis Test.

\begin{tabular}{|c|c|c|c|c|c|c|}
\hline \multicolumn{7}{|c|}{ Results of Hypothesis Test } \\
\hline Hypotheses & Independent Variables & Dependent Variables & Estimate & p-value & Signification & Note \\
\hline $\mathrm{H}_{1}$ & Long-Term Relationship & Information Technology & 0.424 & 0.000 & $<0.05$ & Sig \\
\hline $\mathrm{H}_{2}$ & Long-Term Relationship & Information Sharing & 0.688 & 0.000 & $<0.05$ & Sig \\
\hline $\mathrm{H}_{3}$ & Long-Term Relationship & Supply Chain Integration & 0.269 & 0.000 & $<0.05$ & Sig \\
\hline $\mathrm{H}_{4}$ & Long-Term Relationship & Supply Chain Performance & 0.485 & 0.000 & $<0.05$ & Sig \\
\hline $\mathrm{H}_{5}$ & Information Technology & Supply Chain Integration & 0.076 & 0.07 & $<0.1$ & Sig \\
\hline $\mathrm{H}_{6}$ & Information Technology & Supply Chain Performance & 0.117 & 0.028 & $<0.05$ & Sig \\
\hline $\mathrm{H}_{8}$ & Supply Chain Integration & Supply Chain Performance & 1.174 & 0.000 & $<0.05$ & Sig \\
\hline $\mathrm{H}_{9}$ & Information Sharing & Supply Chain Performance & 0.065 & 0.358 & $>0.05$ & Not Sig \\
\hline
\end{tabular}

Source: AMOS Program, 2015

Table 2 shows that $\mathrm{H} 9$ is not significant because it has pvalue above 0.05 , so the level of trust relationships between variables in this hypothesis is at a level below 95\%. The hypotheses are significant at the 0.05 alpha H1, H2, H3, H4, $\mathrm{H} 6, \mathrm{H} 7$ and $\mathrm{H} 8$, because those hypotheses have p-value < 0.05 , whereas $\mathrm{H} 5$ generates hypotheses with significance at $\mathrm{p}$ $<0.1$. The interpretation in more details are as follows:

i) Testing Hypotheses 1 (H1) generates path coefficient (estimate) Long Term Relationships significantly effect Information Technology with $\mathrm{p}$-value $=0.000$ (less than alpha 0.05 ) to estimate the value of 0.424 . This result indicates that the longer-term relationship will increase the usage length of the Information Technology.

ii) Testing Hypothesis $2(\mathrm{H} 2)$ generates path coefficient (estimate) of Long-Term Relationships significantly effect Sharing Information with $\mathrm{p}$-value $=0.000$ (less than alpha 0.05 ) to estimate the value of 0.688 . This result indicates that the longer the Relationships will further improve information sharing. Long-term relationship is a social capital, where the quality of long-standing relationships will increase the tendency to share information.

iii) Testing Hypotheses 3 (H3) generates path coefficient (estimate) of Long Term Relationships significantly effect Supply Chain Integration with p-value $=0.000$ (less than alpha 0.05 ) to estimate the value of 0.269 . This result indicates that the longger the term relationship will further enhance the Supply Chain Integration.

iv) Testing Hypotheses 4 (H4) generates path coefficient (estimate) of Long Term Relationships significantly effect Supply Chain Performance with p-value = 0.000 (less than alpha 0.05 ) to estimate the value of 0.485 . This result indicates that the longer the Term Relationships will further improve Supply Chain Performance.

v) Testing Hypotheses 5 (H5) generates path coefficient (estimate) of Information Technology significantly effect Supply Chain Integration with $\mathrm{p}$-value $=0.07$ (greater than alpha of 0.05 , but still smaller than 0.1 ) to estimate the value of 0.076 . This result indicates that the better the Information Technology will further enhance the Supply Chain Integration.

vi) Testing Hypotheses 6 (H6) generates path coefficient (estimate) of Information Technology significantly effect Supply Chain Performance with $\mathrm{p}=0.028$ (less than alpha 0.05 ) to estimate the value of 0.117 . This result indicates that the better the Information Technology will further improve Supply Chain Performance.

vii) Testing Hypotheses 7 (H7) generates path coefficient (estimate) of Supply Chain Integration significantly on Information Sharing with $\mathrm{p}=0.012$ (less than alpha 0.05 ) to estimate the value of 0.638 . This result indicates that the better Supply Chain Integration will further enhance the Information Sharing.

viii) Testing Hypotheses 8 (H8) generates path coefficient (estimate) of Supply Chain Performance significantly effect Supply Chain Integration with $\mathrm{p}$-value $=0.000$ (less than alpha 0.05 ) to estimate the value of 1.174. This result indicates that the better Supply Chain Integration will further improve Supply Chain Performance. 
ix) Testing Hypothesis 9 (H9) generates path coefficient (estimate) of Sharing Information is not significantly effect Supply Chain Performance with p-value = 0.358 (greater than alpha 0.05 ) to estimate the value of 0.065 . This result indicates that the Information Sharing does not affect Supply Chain Performance. The researh model is shown in the following figure.

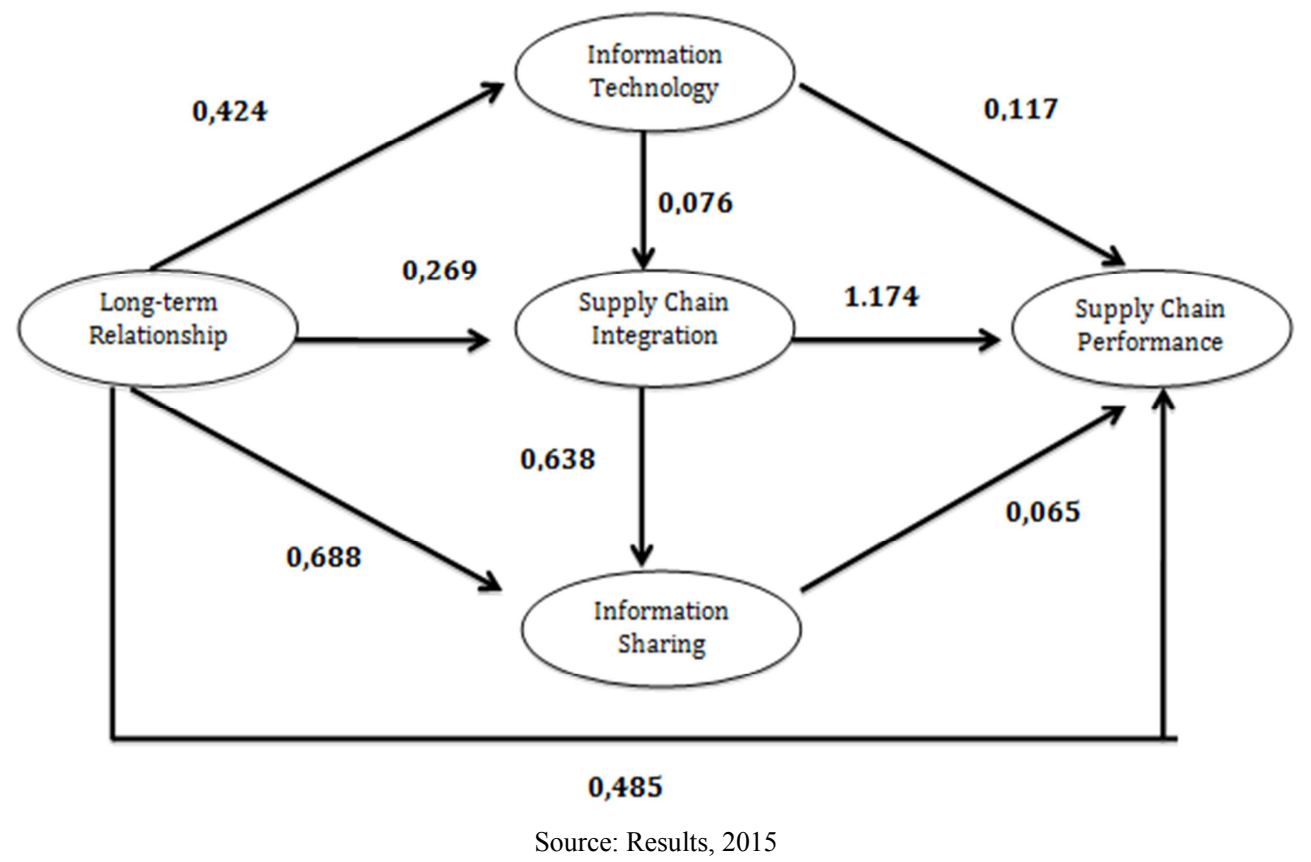

Figure 2. Relationship between Latent Variables Model.

Based on Figure 2, there are findings were quite interesting, first, found that the variable information technology have lower significant effect than others, indicating that the use of information technology is still insufficient in SMEs in Malang. To produce maximum results, the improvement in the use of information technology must be improved. Second, sharing information is less influence on the supply chain performance, this indicates that the quality of information sharing is still low so it doas not affect significantly the supply chain performance.

From the findings it can be concluded that information technology and information sharing in Malang still weak, eventhough both variables is a chain of interrelated and affect other variables. So that the necessary improvement of information technology and information sharing in order to generate maximum performance of the supply chain.

\subsection{Discussion on the Relationships Between Variables}

Relationships between variables have been described in previous discussions statistically, so that in this section will be discussed in greater detail with the findings of the study is expected to clarify this.

\subsubsection{The Influence of Long Term Relationships on Information Technology}

Testing the effect of long-term relationship to information technology, to produce a positive influence signifikan. The result is supported by several previous studies that, the longer and sustainable relationship, the more influence a company uses information technology $[4,16]$

Behaviour of SMEs in Malang in establishing long-term relationships with suppliers and consument do not accompanied by a cooperation contract, but have trust that based in Social Capital. SMEs intended to cooperate and deal with suppliers and customers if you get the order, while the majority of SMEs didn't get continuous orders. Although not get the continuous orders, SMEs are still in a relationship with their partners, such as the suppliers partner. Orders were stalled because of lack of orders, will not break any buyer and supplier relationship. If in suddenly, have no order or in seasonal orders, supplier partners are always ready to meet the supply for SMEs.

These figures show that SMEs relations with its partners are always intertwined and in the long term. Trust and dependency of SMEs and their partners and the development of information technology have an impact on the implementation of information technology needs. SMEs can feel the importance of the use of information technology, in order to more efficiently run their business operations.

Based on the above statement, it is recommended from the results of the long-term relationship to information technology is that long-term relationships on SMEs can be followed by the use of information technology is more optimal. The development of globalization, the demands for speed of information and communication cost savings increasingly urgent applied for SMEs, particularly those with export orientation. 


\subsubsection{The Effect of Long-Term Relationship on Sharing Information}

Sharing information with regard to how the SME and its partners exchange information to support its operations and open evaluation and operational plans. Long-term relationship, which exists between the SME and its partners, is the opportunity to conduct information sharing [4]. Tests were carried out to produce a positive effect and significant correlation between long-term relationships and share information.

Long-term relationship between the SME and its partners has main purpose to build a trust and dependence. SME dependence on consumers, making SMEs always tried to serve customers well. Sudden orders, the number of orders that exceed production capacity, the need for innovation on consumer demand are the things that need to be immediately informed in SMEs other partners, such as suppliers. Longterm cooperation that has existed, facilitate SMEs and partners to convey information quickly, and to respon immediately. Information sharing does not always use information technology, but the use of information technology may save the information delivery.

SMEs in Malang largely implement share information because this activity is able to maintain or strengthen relationships with suppliers as well as with potential customers. SME owners who have experience or a business trip more than five years is more easily share information. This is because the information sharing relates to the trust between SMEs and their supply chain partners. In this case, SMEs have been running the business long time enough hence they may know the characters more and the advantages and disadvantages of its supply chain partners.

SME in Malang already own capital to share information, to always maintain mutual confidentiality of data / information transmitted and relationships with supply chain partners long standing, makes the need for data / information delivered quickly in order to maintain on time services to the customers.

\subsubsection{The Effect of Long Term Relationship on Supply Chain Integration}

Studies that tested the effects of long-term relationships along the supply chain integration have not much been done. The reason researchers to test the effects of long-term relationship to the the supply chain integration is developing a research conducted by [4]. [4] conducted a study to test the effects of a long term relationship to information technology, information sharing and the of the supply chain performance, logistics integration and test variables on the supply chain performance, but does not test the direct affect of long-term relationships on the logistics integration.

The definition of logistics integration is to coordinate with both the flow of material from the supplier to the company, resulting in the smooth running of the production process. The study provides empirical evidence that an effective external logistics integration engendered by long-term relationships and integration of information (information technology and information sharing). Integration of material flow should be supported by the integration of information flow. These findings indicate the effect of long-term relationship on logistics integration. On the other side, supply chain does not only integrate the material flow, but also the information flow to and from suppliers, so that it appears variable supply chain integration.

Testing a long-term relationship to the supply chain integration, results in significant effect. These results occur because of a boost of confidence and commitment among SMEs with supply partners. The supply chain integration which means combining activities that are in the supply chain can not be performed well without trust and commitment. Coordination and confidence can trigger that is incorporated in the supply chain to be more responsible in the production of services as measured by time, quality, and capacity. Demands for maintaining continuous integration encourages SMEs to maintain the quality of service that will ultimately lead to the production costs, customer satisfaction, and profitability.

Customer satisfaction is now becoming one of the things that is very considered by most companies or SMEs. In this regard, SMEs are very responsive on consumer desire that is fickle. Flexibility of SMEs in respond to the consumers' wants will bring some benefits to the SMEs such as sales increase. The flexibility of SMEs to the consumer, followed by SMEs Flexibility Integration from suppliers to other suppliers, SMEs and consumers in the supply chain are woven advantage to respond consumers' desires and expectation.

\subsubsection{The Effect of Long Term Relationship on Supply Chain Performance}

The effect of long-term relationship on supply chain performance is evidenced by the results of hypothesis testing that shows significant result. Long-term relationships are built between SMEs and their supply chain partners, in terms of financial results in an increase in market share and sales growth. While from the non-financial SMEs, generate sensitivity to consumer desire, the flexibility of the delivery number and timeliness of delivery.

Financial and non financial performance is getting better can be supported because of the low cost of transaction which is formed from an element of trust. By long-term relationship, suppliers can provide a relatively lower price in order to achieve excellence and loyalty with supply partners than competitors of similar business sharing.

Long-term relationship directly effect on supply chain performance. This indicates that the ability to strengthen the network is very important in addition to the internal capabilities [4]. According to Relations Theory [22], the company needs to complete its internal capabilities with the ability of others to achieve competitive advantage. Another capability that does not possess in the internal environment is in the external environment, like the company's suppliers and customers. Quality improvement and product innovation in SMEs are formed of a share of the supplier in providing input 
to jointly improve supply chain performance.

Current supply chain performance needs to be improved, since the competition is getting higher. [23] introduce a new approach model that can be used by SMEs to evaluate the overall performance of internal and supply chain strategy selection based on external conditions. In recent SMEs' condition in Malang, many of which did not build their business by setting strategy. Planning the organizational structure, establishment of vision, mission and strategy of SMEs are highly required, so that SMEs in Malang can improve their supply chain performance.

\subsubsection{The Effect of Information Technology on Supply Chain Performance}

In this study, information technology result a significant effect on the supply chain performance. The results of this study indicate that the improvement of the implementation of information technology in SMEs in Malang result in the improvement of supply chain performance in SMEs in Malang.

Based on the analysis, the biggest factor in the variable loading of information technology is the coordination between SMEs and suppliers that is done via the internet. This implies that the measurement of information technology implementation are reflected in the use of internet in the coordination among supply chain, may explain the high supply chain performance that is reflected in an increase market share, with the assumption that the use of information technology in SMEs is currently very limited.

The fact that SMEs do not use the optimal information technology may impact on inefficient coordination among supply chain partners. Improved supply chain performance might be supported by a system that is formed between the supply chain partners.

Information technology significantly and positively affects supply chain performance of SMEs in Malang, supported by a system that has been formed. SMEs in Malang already have systems in meeting consumer desires, and how to deal with suppliers that effective, especially on the sudden booking, fluctuating, and innovative product orders. The information system that is formed today helps to improve the supply chain performance in meeting consumer desires. SMEs responsiveness to customer orders a sudden, fluctuating or product innovations that will and desired by consumers. Implementation of information technology is not optimal, resulting in a positive effect on the performance of the supply chain.

\subsubsection{The Effect of Information Technology on Supply Chain Integration}

The analysis results of the information technology integration and supply chain shows the effect on the information technology supply chain integration. These results indicate that the better implementationof information technology the better supply chain integration in SMEs Malang will be run. Based on the analysis, the largest factor loading of information technology is an indicator of coordination between SMEs and suppliers that is done via the internet. This means that the implementation of information technology is reflected in the use of internet in the coordination among supply chain, may explain the high integration of the supply chain that is reflected in the integration of financial flows.

However, in reality, in implementing information technology, SMEs still use mobile phones with limited facilities, namely to call and do a short message service. Coordination and communication of SMEs with its partners in the operational activities will be more efficient if using information technology. Limitations of human resources expertise of SMEs in information technology bring about the non optimal implementation of information technology. SME in Malang only use a handheld telephone vasilitas (for mobile phones) to call and do a short message (sms). Technology increasingly sophisticated mobile phones, is not used optimally. SMEs reflect the implementation of information technology in the information system that is connected with its supply chain partners.

From above description, it can be concluded that the system already built in SMEs together with its supply partners, should be improved not only by mobile phones but also musat use computers. Supposedly with information technology training that has been done, SMEs can use a computer to perform correspondence by e-mail, web to market a product, and to coordinate with their supply chain partners.

\subsubsection{The Effect of Supply Chain Integration on Supply Chain Performance}

Integration is an important concept for the success of supply chain management. For the implementation of supply chain management requires the integration process that starts from procurement, production, and distribution [24]. Integration process running from one company to another company in the supply chain partners and form a system. The system in place is known as the value system [5, 25]. Value system is formed from the value chain of each company in the supply chain, becomes an integration and synchronization. Alignment in the integration of the supply chain to make the company's operations run easily, thus supporting the performance of the supply chain.

The integration of the supply chain in SMEs in Malang affects supplies chain performance. As discussed previously, the perception of SMEs to supply chain integration, more likely on the integration of financial flows, namely that SMEs get the ease of making payments on suppliers.

Ease of SMEs in supplier payments, resulted in an increase in the market share of SMEs and SME flexible in terms of delivery and capacity. This indicates that the role of the SME suppliers very big impact in the supply chain integration. The ease and smoothness of dealing with suppliers may impact on customer satisfaction in the delivery of the product, thereby will increase its market share.

\subsubsection{The Effect of Supply Chain Integration on Share Information}

Results of testing the hypothesis in this study shows that 
the activity of the supply chain integration effect information sharing. In empirical conditions based on the mean value shows that SMEs are already implementing supply chain integration well. The results illustrate that the loading factor of integration of financial flows are the dominant influence of supply chain integration, such as transactions between SMEs with supply partners to produce a good performance as evidenced by the ease of payment transactions with consumers and ease of payment transactions with suppliers. However, this result is not accompanied by an improvement in the financial administration.

SMEs and supply chain partners who are already doing a long-term impact on the ease of integration in financial flows, especially in getting the ease of making payments to the suppliers. The behavior of long-term relationships, namely the dependence between SMEs and supply chain partners and suppliers to make SMEs more flexible payment transaction. This affects the ease in providing data / information quickly in accordance with the needs of decision-making.

\subsubsection{The Effect of Information Sharing on Supply Chain Performance}

Information sharing is an activity in communicating the data and information required bySMEs and their supply chain partners in their operational activities. In wider coverage, SMEs and partners can synchronize their supply strategies, plans, and objectives of each company, so that the supply chain operations can be run more easily. Most companies are actively enough in providing such information to companies in its supply chain, as it would appear fears of losing control of the business.

Respondents interprate share information between SMEs and supply chain partners mutually maintain the confidentiality of data / information transmitted, while the most dominant indicator that effect information sharing are SMEs and supply chain partners are willing to transmit data / important information. Supply chain performance of the financial side in SMEs has increased market share, while from non-financial perspective of the respondents tend to be on that SMEs responsive to the customers' needs, whereas SMEs flexible delivery and capacity is the most dominant support to the supply chain performance.

Results hypothesis resist the effect of share information on the supply chain performance, bring some consequences as follows:

1. Social capital in SMEs does not form social glue. This is because SMEs somewhat reluctant to share it with other elements in the supply chain, for fear of losing control [27]. SMEs need to do an activity that can make their interrelationships and dependencies between elements in the supply chain. The linkage and dependence can create SME and elements in the supply chain can be more transparent in conducting information sharing for improving supply chain performance.

2. Quality information is lacking to support the supply chain. In the survey tend to show the results that respondents would support the informations sharing, even $59 \%$ of respondents agree to share information. However, it turns out the research find that the information sharing was not found to be significant to the supply chain performance, with consideration of the matter, the possibility of the information being used is less precise so unfavorable performance of the supply chain. This is because the SMEs differ from large businesses that have more resources, so information in alleged big business is more qualified than in the SMEs.

\subsection{Indirect Effect Analysis}

Indirect relationships generally reinforce the strength of the relationship as it involves mediation variables. In this study, the mediation variables reinforce the strength of the relationship of the endogenous and exogenous variables. In regards to the effect of supply chain performance, the variable of long-term relationship between the three variables that can strengthen the relationship. Of the three, supply chain integration has the strongest effect. This is due to supply chain integration has a very strong connection with supply chain performance, as shown by a value of 1.174 in the Figure 2.

This indicates that SMEs in Malang have a very good supply chain integration, so it can affect the supply chain performance. Supply chain integration is not only very capable for building relationships with the supply chain performance, but also capable for sharing information, wherein the second image this variable has a relationship of 0.638 with information sharing.

In conclusion, supply chain integration strengthen relationships among variables. This is an interesting finding, due to the weakness in the information technology and information sharing can be covered by the supply chain integration. This means that the supply chain integration has a very important role in this chain, so keep in mind to strengthen the use of information technology will strengthen the supply chain integration, which in turn will strengthen the tendency to share information in order to maximize the supply chain performance.

Table 3. Indirect Effect Results.

\begin{tabular}{llll}
\hline Eksogen Variable & Mediator Variable & Endogen Variable & Indirect Effect \\
\hline Long-Term Relationship & Technology Information & Supply Chain Performance & 0.528 \\
Long-Term Relationship & Information Sharing & Supply Chain Performance & 0.529 \\
Long-Term Relationship & Supply Chain Integration & Supply Chain Performance & 0.800 \\
Technology Information & Supply Chain Integration & Information Sharing & 0.714 \\
\hline
\end{tabular}

Source: Reserearch Results, 2015 


\section{Conclusion}

Based on the above discussions, can be concluded that the long-term relationship between SMEs and supply chain partners can improve the implementation of information technology, supply chain integration, information sharing and supply chain performance. Long-term relationship also may also bring about trust between SMEs and their supply chain partners. Hence, the SMEs and their supply chain partners can enhance the activities of supply chain management. In addition, long-term relationship has also direct effect in improving supply chain performance. The most visible indicators of the performance of the supply chain is an increase in return on investment and assets, sales growth, market share expansion, and increased innovation and development of production. In relation to the indirect effect, long-term relationship has indirect effect on the supply chain performance through the mediating variable information technology, supply chain integration and information sharing. However, the use of Information Technology to SMEs is not done optimally. Although the are limitations on competent human resources in information technology, capital, and the barriers faced by SMEs in implementing information technology, the use of information technology is able to improve supply chain performance. Furthermore, supply chain integration on SMEs generate a significant effect on the supply chain performance. Likewise, the integration of financial flows, integration of material flow and integration of information flow are supporters of variable dimension of supply chain integration. Sharing information is an activity that supports collaboration among supply chain partners and SMEs. Trust that exists among supply chain partners is highly valued. Finally, information technology, supply chain integration and information sharing can mediate between long-term relationship and supply chain performance.

\section{Recommendations}

Based on the conclusions and discussion of the results of this study, the structured advice and recommendations are firstly, supply chain management applications that have been performed by the manufacturer cannot entirely be adopted by SMEs in Malang. SMEs need to do it gradually, according to the needs and capabilities of SMEs. The most important thing that should be done by the SMEs is to strengthen the internal environment, namely creating a clear business plan, including SME strategy planning, the integration between each element in SMEs, so that SMEs will be able to compete. Technological developments and the opening of the free market, requires for SMEs to optimize the use of information technology in business. Secondly, SMEs need to manage the business administration formally through the preparation of the legality of business licensing and the formation of a formal contract to develop access to finance / capital and to avoid the uncertainty of the business environment. Thirdly, development of production technologies also contribute to the urgent need to balance the development of information technology in order to improve business performance. In this case, the government need to collaborate with universities through mentoring program and the provision of production resources (such as labor, equipment and supplies production) quality. Fourthly, in order to improve the quality and production capacity, SMEs need to develop information technology to the upstream (suppliers) and downstream (consumers) to make production planning and decision making processes running fast and accurately. The limitations of investment capital owned by SMEs encourage SMEs in Malang to establish a group or cluster system so that information technology can be managed optimally with lower costs.

\section{References}

[1] Li, Suhong \& Ragu-Nathan, Bhanu \& Ragu-Nathan, T \& Rao, Subba. (2006). The Impact of Supply Chain Management Practices on Competitive Advantage and Organizational Performance. Omega. $\quad 34 . \quad 107-124$. 10.1016/j.omega.2004.08.002.

[2] Anatan, Lina. 2010. Supply Chain Management Teori dan Aplikasi. Alfabeta. Bandung.

[3] Koçuglu, Ipek., Salih Zeki Imamoglu, Hüseyin Incea, Halit Keskina. 2011. The effect of supply chain integration on information of sharing: Enhancing the supply chain performance. Procedia Social and Behavioral Sciences.

[4] Prajogo, Daniel and Jan Olhager. 2012. Supply chain integration and performance: The effects of long-term relationships, information technology and sharing, and logistic integration. International J. Production Economics.

[5] Heizer, J. H., and Render, B. Principles of Operation Management. 2008. New York: Pearson Prentice Hall.

[6] Aprianiningsih, Hesti, Achmad Holil Noor Ali, Anisah Herdiyanti. 2014. Analisis Pengaruh Implementasi Teknologi Informasi terhadap Kinerja Rantai pasokan dengan Integrasi Rantai pasokan sebagai mediator pada sektor Industri Tekstil dan Produk Tekstil (TPT). ITS Paper.

[7] Levy, M., Powell, P. and Yetton, P. (2001), "SMEs; aligning IS and the strategic context", Journal of Information Technology, Vol. 16 No. 3, pp. 133-44. (PDF) Supply chain management practices of SMEs: From a business growth perspective. Available from: https://www.researchgate.net/publication/220306368_Supply_ chain_management_practices_of_SMEs_From_a _business_gr owth_perspective [accessed Oct 23 2018].

[8] Johnson, M. \& Mena, C. 2008. Supply Chain Management for Servitised Products: A Multi-industry Case Study. International Journal of Production Economics, 114 (1), 27-39

[9] Bagheri, Mohammad., Mahdi \& Abdul, Abu \& Soltani, Iraj \& Mardani, Abbas \& Kish Hazrat Soltan, Ehsan. (2014). The Role of Su pply Chain Antecedents on Supply Chain Agility in SMEs: The Conceptual Framework. Jurnal Teknologi. 66. 53-60. 10.11113/jt.v66.1826. 
[10] Ariani, Desi and Dwiyanto, Bambang Munas. 2013. Analisis Pengaruh Supply Chain Management terhadap Kinerja Perusahaan (Studi pada Industri Kecil dan Menengah Makanan Olahan Khas Padang Sumatra Barat. Diponegoro Journal of Management.

[11] Simchi-Levi, David, Phillip Kaminsky, and Edith Simchi-Levi (2003). Designing and Managing the Supply Chain: Concepts, Strategies, and Case Studies, Homewood, IL: Richard D. Erwin.

[12] Pujawan, I Nyoman. 2010. Supply Chain Management. Institut Teknologi Sepuluh Nopember, Surabaya.

[13] P. Jongkyung, S. Kitae, T. Chang, (2010), An integrative framework for supplier relationship management, Industrial Management \& Data Systems Vol. 110 No. 4, 2010 pp. 495515. (PDF) A Conceptual Integrated Model to Supplier Relationship Management - From the Manufacturing Industry Perspective. Available from:

https://www.researchgate.net/publication/264211900_A_Conc eptual_Integrated Model to Supplier Relationship_Manage ment_-_From_the_Manufacturing_Industry_Perspective [accessed Oct 23 2018].

[14] Hwang, Y. D., Lin, Y., Lyu, J. 2008. The performance evaluation of SCOR sourcing process: The case study of Taiwan's TFT-LCD industry. International Journal of Production Economics 115, 411-423.

[15] Chopra, S., Meindl, P. 2004. Supply Chain Management: Strategy, Planning and Operation, third edition, Prentice Hall, New Jersey, USA.

[16] Sheu, C., Yen, H. R., \& Chae, B. (2006). Determinants of supplier-retailer collaboration: Evidence from an international study. International Journal of Operations \& Productions Management, 26 (1), 24-49.

[17] Central Bureau of Statistics (BPS) of East Java. 2013. The number of Small and Medium Enterprises (SMEs) in Malang, East Java. Available on https://jatim.bps.go.id/. Access online on 13 Oct 2018.
[18] Hair, Joseph F., Bill Black, Barry Babin, Rolph E Anderson and Roland L Tatham. 1998. Multivariate Data Analysis. Upper Saddle River: person Education, New York.

[19] Kline, R. (2005). Principles and practices of structural equation modeling ( $2 \mathrm{n}$ ed.). New York: Guilford Press.

[20] Bentler, P. M. (1998). EQS structural equations program manual. Encino, CA: Multivariate Software.

[21] Omsa, Sirajuddin, Abdullah, Ibrahim H., and Jamali, Hisnol. 2017. Five Competitive Forces Model and the Implementation of Porter's Generic Strategies to Gain Firm Performances. Science Journal of Business and Management. Vol. 5 (1): 916, doi: 10.11648/j.sjbm.20170501.12.

[22] Dyer, Jeffrey H. and Singh, Harbir. 1998. The Relational View: Cooperative Strategy and Sources of Interorganizational Competitive Advantage. The Academy of Management Review. 23 (4) · October 1998. DOI: 10.2307/259056.

[23] Alomar, Madani. Zbigniew J. Pasek. 2014. Linking supply chain strategy and processes to performance improvement. Proceedings of the 47th CIRP Conference on ManufacturingSystems.

[24] Mentzer, John T., DeWitt, William., Keebler, James S., Min, Soonhong., Nix, Nancy W., Smith, Carlo D., and Zacharia, Zach G. 2001. Defining Supply Chain Management. Journal of Business Logistics, Vol. 22 (2), https://doi.org/10.1002/j.2158-1592.2001.tb0000q.x.

[25] McLeod, Raymond and Schell, George P. 2007. Management Information Systems. The University of Virginia: Pearson/Prentice Hall.

[26] Ulwan, M. N., 2014. Teknik Pengambilan Sampel Dengan Metode Purposive Sampling. http://www.portal-statistik.com/

[27] Benton, W. C. and Maloni, M. 2005. The influence of power driven buyer/seller relationships on supply chain satisfaction. Journal of Operations Management. Vol. 23, pp. 1-22. 